IZA DP No. 6130

Long Shadows of History:

Persecution in Central Europe and Its Labor Market Consequences

Michal Myck

Radim Bohacek

November 2011 


\title{
Long Shadows of History: Persecution in Central Europe and Its Labor Market Consequences
}

\author{
Michal Myck \\ CenEA, DIW Berlin \\ and IZA
}

Radim Bohacek

CERGE-El

\section{Discussion Paper No. 6130 \\ November 2011}

IZA

\author{
P.O. Box 7240 \\ 53072 Bonn \\ Germany
}

\author{
Phone: +49-228-3894-0 \\ Fax: +49-228-3894-180 \\ E-mail: iza@iza.org
}

\begin{abstract}
Any opinions expressed here are those of the author(s) and not those of IZA. Research published in this series may include views on policy, but the institute itself takes no institutional policy positions.

The Institute for the Study of Labor (IZA) in Bonn is a local and virtual international research center and a place of communication between science, politics and business. IZA is an independent nonprofit organization supported by Deutsche Post Foundation. The center is associated with the University of Bonn and offers a stimulating research environment through its international network, workshops and conferences, data service, project support, research visits and doctoral program. IZA engages in (i) original and internationally competitive research in all fields of labor economics, (ii) development of policy concepts, and (iii) dissemination of research results and concepts to the interested public.
\end{abstract}

IZA Discussion Papers often represent preliminary work and are circulated to encourage discussion. Citation of such a paper should account for its provisional character. A revised version may be available directly from the author. 
IZA Discussion Paper No. 6130

November 2011

\title{
ABSTRACT \\ Long Shadows of History: Persecution in Central Europe and Its Labor Market Consequences
}

\begin{abstract}
We analyze the extent and effects of job-related persecution under communist regimes in the Czech Republic and Poland using a representative sample of individuals aged 50+ from the Survey of Health, Ageing and Retirement in Europe. Retrospective information collected in the SHARELIFE interview offers a unique chance to relate past and current labor market outcomes to experiences of persecution reflecting the historical developments in Central Europe in the 20th century. Individual level data with details on labor market histories is matched with information on the experiences of state oppression. On-the-job persecution is found to have significant effect on job quality assessment and is strongly related to reporting of distinct periods of stress in both countries. Consequences of on-the-job persecution seem to have been much more severe and longer lasting in the Czech Republic, with significant financial effects of job loss or discrimination. This is explained by the greater degree of state control over the labour market in the former Czechoslovakia compared to Poland and different characteristics of the dissident groups in both countries.
\end{abstract}

JEL Classification: J71, J28, N44, I19

Keywords: labor discrimination, persecution, job satisfaction, life histories, history of Central Europe

Corresponding author:

Radim Bohacek

CERGE-EI

Politickych veznu 7

11121 Prague 1

Czech Republic

E-mail: radim.bohacek@cerge-ei.cz

\footnotetext{
* This paper uses data from SHARE release 2.3.1, as of July 29th 2010 SHARELIFE release 1, as of November 24th 2010. The SHARE data collection has been primarily funded by the European Commission through the 5th framework programme (project QLK6-CT-2001- 00360 in the thematic programme Quality of Life), through the 6th framework programme (projects SHARE-I3, RII-CT-2006062193, COMPARE, CIT5-CT-2005-028857, and SHARELIFE, CIT4-CT-2006-028812) and through the 7th framework programme (SHARE-PREP, 211909 and SHARE-LEAP, 227822). Additional funding from the U.S. National Institute on Aging (U01 AG09740-13S2, P01 AG005842, P01 AG08291, P30 AG12815, Y1-AG-4553-01 and OGHA 04-064, IAG BSR06-11, R21 AG02169) as well as from various national sources is gratefully acknowledged (see www.share-project.org for a full list of funding institutions). The SHARE project in the Czech Republic is supported by the Ministry of Education, Youth and Sports of the Czech Republic. The usual disclaimer applies.
} 


\section{Introduction}

Over twenty years after the first free elections in Poland in June 1989 and the "velvet" revolution in Czechoslovakia little is known about the consequences of the former regimes' oppressive nature on the well-being of their populations. This applies both to the question of well-being at the time as well as to the long term consequences of the years spent under communism. It can be explained partly by the unavailability of reliable data on the effect of the systems on individuals from the time prior to the fall of the regimes as well as on the situation of the populations immediately after the change. Lack of quantitative studies applies also to evidence on the nature and functioning of labor markets, which under communist regimes were subject to very tight control both through the process of wage determination, through jobs allocation and ability to affect quality of work. The workplace was often the place where the power of the state over the individual presented itself most clearly, with the ability to affect people's lives in the short and in the long term. In this paper we address the question of how persecution during communism in the Czech Republic and Poland reflected itself on labor market outcomes, both at the time and from the point of view of a long term perspective on career development and satisfaction. To our best knowledge it is the first study to address these issues directly in quantitative manner.

For this purpose we use data from the Survey of Health, Ageing and Retirement in Europe (SHARE) in the SHARELIFE module conducted in 2008/09. ${ }^{1}$ Detailed information on the experience of persecution contained in this module is combined with a rich set of data on labor market and earnings history, assessment of the work place and overall career. While the data we use for the analysis relies fully on retrospective information, we argue that the careful design of the survey allows us to draw causal conclusions on the effects of persecution. In a recent paper describing the relationship of the experience of persecution with more general current outcomes such as health and life satisfaction (Bohacek and Myck (2011)) we showed that over twenty years after the fall of the old regimes we can still identify strong and significant effects of experiences of persecution. This is despite the passage of time, the years lived under new democratic regimes and despite the fact that we can only examine it among those who survived long enough to participate in the survey. All these factors imply that any effects we find are most likely lower bounds of the true effects. ${ }^{2}$ The analysis presented

\footnotetext{
${ }^{1}$ The Survey of Health, Ageing and Retirement in Europe (SHARE) is a multidisciplinary and cross-national panel database of micro data on health, socio-economic status and social and family networks of more than 45,000 individuals aged 50 or over.

${ }^{2}$ In Bohacek and Myck (2011) we also showed that the retrospective information in the SHARE-
} 
in this paper looks at the data in much more detail and considers very specific range of current and past outcomes with a particular focus on the labor market.

Rummel (1994) defines persecution as "the responsibility of a government, regime, or self-governing group for an unarmed and non-physically threatening person's death, imprisonment, dispossession, deprivation of individual rights or freedoms". Starting with the German aggression in September 1939, through Nazi and Soviet occupation of Central European territories, post-war forced migration and years of Soviet-controlled communist government, the populations of Central and Eastern Europe suffered various forms of oppression. Many of the victims are no longer alive due to direct loss of life at the hands of the regimes. The length of life of numerous others has been affected by deterioration of health and economic condition resulting from persecution. Nevertheless among those individuals who participated in the SHARELIFE survey we still find a substantial proportion of individuals who experienced persecution.

The data from the SHARELIFE survey offer a unique and perhaps the last opportunity to analyze the effects of the major historical events of the twentieth century on the welfare of European populations. It offers a glimpse of evidence on the nature of the labor market and labor market relations under communism, the type of persecution individuals were subjected to, and the reasons behind it. The range of the results presented in this paper as well as the degree of their statistical significance show how powerful the state was versus the individual and how profoundly people's lives were affected. We show how different the two countries were in terms of the prevalence of persecution in the workplace, and the type and strength of consequences that individuals were faced with.

The results of the paper show that in both countries, individuals who were subjected to job-related persecution are around $40 \%$ more likely to report having experienced a distinct period of stress. On the job persecution among Czech respondents is also associated with the experience of financial hardship. The unique content and structure of SHARELIFE interview allows us to identify persecution in specific jobs to analyse the effects of on-the-job persecution on earnings in subsequent jobs. In both countries persecution has had a significant effect on the assessment of quality of work in specific jobs. Experience of persecution is correlated with recurrent conflicts, unfair treatment and lack of adequate support in the workplace. In the Czech Republic, the communist government had a very high degree of control over job assignments in the labor market. We find this reflected in the degree of the effects of persecution-related job LIFE data closely matches with historical developments in the countries of Central Europe. 
loss on the level of subsequent earnings, which fall by 27\%. Persecution in the Czech Republic affected most frequently people with tertiary education which - together with the high degree of financial penalty related to persecution - may explain why in the Czech data we find very strong effects of persecution on dissatisfaction with work achievements and major career disappointment (65\% and 34\%, respectively). On the other hand in Poland, although we find significant effects of persecution on job quality, there is no evidence on significant financial penalties in subsequent jobs. Moreover, the relationship between experience of on-the job persecution in Poland and overall career assessment is much weaker than in the Czech Republic. We interpret these findings as confirmation that the Polish communist governments did not have such a complete control over the labor market as their southern counterparts. Moreover, weaker financial consequences of persecution may relate to the fact that unlike in the Czech Republic, where the dissident movement largely consisted of population with higher education, in Poland it was centered largely around labor unions and industry workers whose financial penalties resulting from persecution could have been proportionally smaller.

The paper is organized as follows. In Section 2 we briefly document the periods of most intensive deprivation of rights and freedoms between the end of World War II and the fall of communism in Czechoslovakia and Poland. Section 3 presents the structure of the SHARELIFE interview and describes the data we use for the analysis. It describes the extent and form of persecution in the Czech Republic and Poland reflected in the SHARELIFE data. In Section 4 we show results of job-related persecution on financial hardship and stress, assessment of main job quality, on earnings and overall career assessment. Section 5 concludes the paper. The Appendix contains the main SHARELIFE questions used in the analysis.

\section{Brief historical background}

Over half of respondents in the SHARE sample in the Czech Republic and Poland (respectively $56 \%$ and $52 \%$ ) were born before 1946, and thus experienced the horrors of World War II and later, like the other half born between 1946 and 1957, lived most of their adult lives under the communist regimes. The types of persecution these populations were subjected to included therefore both the oppression by the Nazi and Soviet regimes. These included the Holocaust, genocide and reprisals against occupied populations, imprisonment or concentration camps, forced labor and resettlement, forced 
military service, various forms of persecution affecting job prospects and education opportunities. The reasons for persecution were political, racial, religious, sexual orientation, class origin, or any other characteristics convenient for the regime in power.

Depending on the age of our respondents, the communist regimes in the Czech Republic (1948-1989) and Poland (1944-1989) covered all or nearly all of childhood and a substantial proportion of their adult lives. The intensity of persecution varied greatly between regimes and time periods. The most intense periods of persecution occurred until 1956, with several hundred thousand persons affected by murder, labor camps, imprisonment, political trials, forced collectivization and resettlement and other acts of violence. In the later periods, the forms of persecution were less severe but continued in the form of restricted access to education or persecution at work, penitary military service, psychiatric confinement, and other restriction of civic freedoms.

The period of most intensive oppression started with the Nazi occupation of Czechoslovakia in 1938-39 and the invasion of Poland by Germany and the Soviet Union in September 1939, but while the end of war activities in 1945 stopped the most atrocious bloodshed, the subsequent communist rule exerted significant pressure on the lives of those who opposed or questioned the legality of the new state and the methods it used to hold on to power. In the case of Poland the end of World War II brought significant border shifts with extensive, often forced (or "wild") population relocation. In Poland there is no clear dividing line between World War II persecution and communism as the latter was imposed immediately by the Soviet forces in 1944, and the population suffered tremendous human losses from both the German and the Soviet side.

\section{INSERT TABLE 1 AROUND HERE}

The communist regime in Czechoslovakia was installed in February 1948 with a direct guidance from the Soviet Union, after a brief period of limited democracy in 1945-1947. The Stalinist period of the most brutal persecution lasted till early 1950s, during which more than 5,000 people were murdered or died as a direct consequence of imprisonment or concentration camps. Intelligentsia, propertied classes, farmers and clergy were the most persecuted groups (for example, in 1950-1951, 48,485 prison and concentration camp sentences, i.e. 39\%, were farmers). Table 1 presents conservative estimates of the worst cases of persecution in the Czech lands. ${ }^{3}$ As a rule the whole

\footnotetext{
${ }^{3}$ The numbers in the Table 1 are almost certainly lower than the real losses due to lack of preserved materials from the 1950 s and those who died after their release from prison or concentration camps).
} 
family suffered with its targeted member: children of persecuted farmers could not attend high schools or university, family members were denied access to jobs they were qualified to, young men were assigned to penal military units. It is the nature of the Communist regime that among the victims were also members of the ruling party. ${ }^{4}$ Besides brutal persecution of political opponents and perceived enemies of the regime, virtually all private productive property (including land) was confiscated without retribution. Private savings were devalued by the monetary reform in 1953. After a brief interlude of relative freedom in 1967 and 1968 during the Prague Spring, the Soviet occupation of Czechoslovakia led to a massive emigration (mostly highly educated and young people) and another wave of persecution that lasted till the fall of the regime in $1989 .{ }^{5}$ This last phase of persecution was mild relative to the $1950 \mathrm{~s}$ but nevertheless affected a significant proportion of the population. It took the form of restriction on job careers, education and other civil liberties. The dissidents (Charta 77 , VONS, and other relatively small dissident groups) were imprisoned and actively persecuted by the authorities.

In Poland, unlike in the Czech Republic, there was no democratic interlude after the end of World War II. The Soviet Union imposed its control of Poland immediately after the Red Army entered its territory in 1944. Political opponents and members of non-communist resistance were arrested, transported to labor camps and murdered. At least 25,000 people, mostly those associated with the Home Army, lost their lives in labor camps created by the Soviets as early as 1944. Other estimates put the number of murdered Home Army soldiers at 60,000 by the Soviets in 1944-1945 plus additional 30,000 murdered in 1944-1947. In the Lublin area more than 50,000 Poles were arrested between July 1944 and June 1945, 40,000 Home Army were deported and many others persecuted. The Soviet regime imposed nationalization of production, heavy industrialization, and collectivization of agriculture. The main wave of nationalization began in 1946 with all enterprises with over 50 employees nationalized without compensation. Poland, however, remained the only Soviet bloc country where private individual farmers dominated agriculture, though collectivized farms dominated on pre-war German areas. The regime met with returning waves of protests and strikes, most notably in 1970 and 1976, which culminated in the formation of Solidarność,

\footnotetext{
${ }^{4}$ The most extensive violent purge swept the leadership of the Czechoslovak Communist party (550,000 members expelled, most of them between 1950 and 1952, see Brzezinski (1958)). Less violent purges occurred in Poland and other countries. Granville (2001) estimates the total number of those in some way purged in the 1948-1956 period in Poland was approximately 350,000. On the average, about one in every four party members were purged.

${ }^{5}$ Barta, Cvrcek, Kosicky, and Sommer (2009) report around 120 direct victims of the occupation in 1968. It is estimated that around 280,000 individuals lost their jobs.
} 
the independent workers' union. It responded by imposing the martial law in December 1981 which once again intensified persecution. Data available on "quantifiable" victims of communist years in Poland is given in Table 2.

\section{INSERT TABLE 2 AROUND HERE}

Those who suffered most under World War II and under communism, lost their lives or had their health badly affected have long died. Many of those who survived the worst periods of persecution belonged to cohorts which could not have been expected to live through to the 2000s. Nevertheless all respondents who took part in the SHARELIFE survey, and who lived in the Czech Republic and Poland under the rule of the old regimes, lived through the horrors of World War II and/or a long period of communist rule. They therefore had to conduct their lives with the overpowering state strongly limiting their freedoms and using various forms of direct and indirect oppression and with the background of official and unofficial information on the most brutal treatment of opponents and critics of the regimes. Importantly, both the Nazi and Communist regimes usually persecuted not only the main target of persecution but also his or her close relatives who were denied access to education, jobs corresponding to their qualification, or otherwise affected by relocation, or even by imprisonment.

It is important to understand that in the 1940-1950s and even 1960s, persecution was usually not the consequence of a choice but rather of a chance of belonging to an ethnic minority, practicing a particular religion, or being born into a household with certain characteristics. It was a matter of survival, long-term incarceration and hard persecution of close relatives. Active opponents of the regime were murdered, sent to concentration camps, or emigrated. Of course, the economic consequences were severe for victims' and their family's career, economic and educational opportunities. On the other hand, in later periods of the post-Stalinist, more appeasing communist system, more and more people were persecuted because they actively opposed or demonstratively boycotted the communist regime. Thus for most of the persecuted people in the 1970s and 1980s, persecution became a choice: it was a question of losing an occupation, career or education (also of family members), i.e. mostly of a lower socio-economic status.

For a general overview of the 20th century Czechoslovak and Polish history of, see Courtois et al. (1999), Naimark (1998), Snyder (2010), or Davies (2005). In the following text we refer to Czechoslovakia as the Czech Republic as the SHARE sample includes only people living within the current borders of the latter. 


\subsection{The Economic System}

After World War II, the Soviet-type system was gradually imposed on all countries of Central and East Europe (see Svejnar (1999) for a survey). It was characterized by central planning, full employment of labor (zero official unemployment) as well as centrally set wages, prices and output targets for state-owned enterprises. All private productive property was nationalized: the size of the private sector was basically zero in Czechoslovakia and negligible in Poland (3.6\% of employment in 1987 in Rutkowski (1996b)). Central planning operated through the 5-year output and investment plans, centralized financial flows, soft budget constraints and foreign trade integrated within the Soviet-bloc trading area, the COMECON. Due to centrally fixed prices, the system displayed varying degrees of shortages and excess demand. There was virtually no association between wages and performance of a firm, incentives for improving skills or investment in R\&D were minimal.

Economic growth in these centrally planned economies typically came from more extensive use of inputs instead of increases in productivity. After a period of heavy industrialization in $1950 \mathrm{~s}$, a significant slowdown in economic performance led to social pressures and attempts at economic reforms that allowed for more liberal economic policies especially in Poland and Hungary.

In theory, employment was guaranteed as well as required. While official unemployment was non-existent, in practice many of those in formal employment were idle. Estimates of over-employment or labor hoarding were estimated by Nesporova (1999) at $15-30 \%$ of the total working time. Ray (1991) shows that the productivity in central and eastern European countries in mid-1980s ranged from around over a third to a half of that in a middle-income OECD country like Austria. All countries had been in a long-term decline in productivity relative to Western Europe.

Wages were regulated by means of wage rate scales for different skills and industries (for more details see Adam (1984)). Differences between these scales reflected the importance attached to different industries (heavy industry and mining) as well as the ideological importance of the working class. In Poland, the ratio of median earnings of blue-to-white collar workers was $0.982 .{ }^{6}$ Rutkowski (1996a) also documents the

\footnotetext{
${ }^{6}$ In the same year, highly paid employees in financial and health care industries were earning $11 \%$ and $18 \%$ less, respectively, than highly paid workers in manufacturing. A highly paid miner was earning $63 \%$ more than a professor in R\&D, and as much as 2.3 times more than a highly paid physician (Rutkowski (1996a)). Boeri and Keese (1992) document wage ratio of non-manual to manual occupations as 1.11 in Czechoslovakia and 1.19 in Poland in 1990. Our estimates in Table 4 are very similar.
} 
low returns on education in 1980s. In Poland, the earnings premium for university education was around $14 \%$ with respect to basic vocational, $18 \%$ to secondary, and $20 \%$ to primary education. In Czechoslovakia in 1988, university education had a premium of $19 \%$ with respect to secondary and $27 \%$ to primary education. These low returns to education partially reflect the low demand for high skills in an economy characterized by lack of incentives for innovation and low total factor productivity growth. ${ }^{7}$ Overall, income distribution was maintained at relatively egalitarian levels: the Gini coefficient of earnings was around 0.23 in Poland in 1970-1980s and even 0.198 in Czechoslovakia in 1987 (Rutkowski (1996a)). Similarly, Boeri and Keese (1992) find that inter-industry wage differentials were low and stable over time.

As the commitment to full employment had been one of the main characteristics of communist regimes, female labor was needed to satisfy the excess demand for labor. Official policy gave women the same educational opportunities as men (resulting in a very high educational attainment of women), proclaimed earnings equality, extremely generous maternity benefits (usually 3-4 years for each child) as well as child day care provision (Adam (1984)). However, the main incentive for female labor market participation $(70 \%$ in 1980 s in Poland and close to $80 \%$ in Czechoslovakia, see Brainerd (2000)) was the low average real earnings that effectively encouraged females to work in order to maintain decent living standards (Rutkowski (1996b)). The gender wage gap, however, in terms of female-male wage ratio, had been comparable to that observed in Western economies. In 1988, women earned on average only 65-71 percent of men's wages (Jackman and Rutkowski (1994) and Atkinson and Micklewright (1992)).

\section{Documenting persecution in SHARE data}

In this section we describe the information which we use from the SHARE data collected in the SHARELIFE interview. We present the data for the Czech Republic and Poland, showing information on the key characteristics of respondents including those which describe their labor market histories and their experience of persecution. As we argue below the structure of the SHARELIFE interview in general and of the persecution section in particular, as well as the sequence in which questions were asked are crucial from the point of view of the interpretation of our results. We begin this section

\footnotetext{
${ }^{7}$ Czechoslovakia had approximately the same educational attainment as OECD countries at that time, while Poland's attainment was much lower (not controlling for quality).
} 
with a brief outline describing how the interview has been designed to support our argument that the results presented here can be given a causal interpretation. The main items of the SHARELIFE questionnaire related to persecution and documentation of labour market experiences described in this section are listed in the Appendix.

\subsection{Interview sequence and identification of on-the-job per- secution}

The main sections of the SHARELIFE interview covered details of accommodation history, family history, labor market history, health history and childhood living conditions and healthcare. The labour market history section asked a number of questions which allow to reconstruct in detail individual labour market histories. It recorded several key characteristics of respondents' jobs, such as the year of starting and ending a job, the job's industry, individuals' occupation and whether it was a full-time or part-time employment. Additionally individuals were asked to give the starting salaries in each of the jobs they had. On the basis of this information we can recreate the entire path of job spells and employment interruptions all the way up to the date of the interview. Additional information in the labour market history section was also collected concerning the main job of respondents' career, defined as "the last job in the career or the occupation that took up most of your working life, even though you might have had other jobs afterwards". In this sub-section respondents were asked a set of questions regarding work conditions in their main job, such as whether they were exposed to conflicts, or whether they were treated fairly.

In the final part of the interview, after details of jobs and life history in other main areas have been recorded, respondents were asked a set of general questions concerning some major life experiences they have had including a set of questions focused specifically on the experience of persecution. The persecution section opened with the main question:

- There are times in which people are persecuted or discriminated against, for example because of their political beliefs, religion, nationality, ethnicity, sexual orientation or their background. People may also be persecuted or discriminated against because of political beliefs or the religion of their close relatives. Have you ever been the victim of such persecution or discrimination?

Conditional on a positive answer to this question followed a series of detailed questions on the form and immediate consequences of persecution. The principal follow-up 
question asked for the main reason for this persecution. ${ }^{8}$ Two further questions were specifically concerned with experiences on the labour market:

- Did persecution or discrimination because of [main reason] ever force you to stop working in a job?

- As a consequence of persecution or discrimination because of [main reason], did you ever experience any of the following during your working life:

1. Denied promotions

2. Assignment to a task with fewer responsibilities

3. Working on tasks below your qualifications

4. Harassment by your boss or colleagues

5. Pay cuts

6. None of these

In each of the two above cases there was a follow-up question which asked about which job the specific form of persecution applied to. In these cases respondents could choose from the list of jobs they had given in the labour market history section. Such a set up facilitates matching the experience of on-the-job persecution with specific jobs. As a result we know in which jobs individuals were discriminated against as a manifestation of persecution, up to the point that they could have lost these jobs for this reason.

In any discussion of the links between conditions and outcomes reported in a retrospective interview, such as SHARELIFE, questions may be raised as to the specific causal relationship between them. This relates of course also to the results which we present below. In our view, however, the structure of the interview outlined above significantly reduces the potential for this source of endogeneity. First of all identification of any job-related persecution is "screened" through the general persecution question and respondents answering this general question do not know that questions on jobrelated persecution will follow. Secondly, the persecution section is at the end of the interview separated from the labour market history section by a significant number of questions on issues unrelated to job quality or life time earnings. This means that respondents first provide details of their labour market history, and only at the end of the interview identify jobs in which they experienced persecution. This structure, we argue, should limit the potential for endogeneity of the relationships we analyse, at least as much as it is possible in a retrospective analysis. It avoids for example the

\footnotetext{
${ }^{8}$ Respondents could choose among: "Your political beliefs", "Your religion", "Your ethnicity or nationality", "Your sexual orientation", "Your background", "Political beliefs or religion of your close relatives", and "Other reasons".
} 
problems which could arise if the question of whether someone has been persecuted in a job followed a question of whether they were treated fairly at work.

\subsection{Sample statistics}

In the SHARELIFE survey 1,846 people aged 50+ were interviewed in the Czech Republic and 1,874 in Poland. Several additional sample selection criteria were applied dictated by the nature of the problem we focus on. One of the crucial items we analyse is individual experiences in the main job of respondents' careers. Because we focus on the oppressive nature of the pre-1990 regimes in the analysis we include only individuals who started their main job before 1990 and who were employees in this main job. ${ }^{9}$ We also leave only those who gave valid information in the case of all the variables we include in the analysis. This leaves us with 1,126 individuals in the Czech Republic and 869 in Poland. Descriptive statistics on these samples are presented in Table 3.

\section{INSERT TABLE 3 AROUND HERE}

The data show considerable differences between the two countries. This applies for example to the level of education with over $19 \%$ of the Czech sample and only about $9 \%$ of the Polish sample declaring at least 14 years of full-time education. ${ }^{10}$ Another indicator relating to the educational background - the number of books at home at the age of 10 also signals large differences between the Czech Republic and Poland. $80 \%$ of the Polish sample state that they had only up to one shelf of books at home at the age of 10 . The corresponding number in the Czech Republic is $44 \%$. The proportion of women in the sample is higher in the Czech sample, which since we condition on availability of job information in the survey, is consistent with higher female employment rates under the old regime compared to Poland.

\footnotetext{
${ }^{9}$ This means for example that individual farmers, still quite common in Poland before 1990 are excluded from the analysis.

${ }^{10}$ We divide education attainment into three levels according to information on the number of years of continuous full-time education. This is constructed using primarily direct information on the number of years of education from the Wave II survey (2006/07) and is complemented for those who did not participate in Wave II with information on when individuals left continuous full-time education from SHARELIFE. The three levels are: less than 10 years, 10-13 years, 14+ years of continuous full-time education, and this broadly corresponds to primary/vocational, secondary and tertiary levels of education in both countries. It must be noted that due to numerous changes in the education system in both countries at the time SHARE respondents attended school, as well as to events such as World War II or post-war migration during which schooling could have been interrupted, there may be measurement error in our definition. The approach we take however, seems to be the most consistent way of distinguishing the levels of education which is at the same time comparable across the two countries.
} 


\section{INSERT FIGURE 1 AROUND HERE}

The second panel of Table 3 presents information on the experience of persecution as recorded in SHARELIFE data. $13.7 \%$ of the Czech respondents in the sample we consider give a positive answer to the general persecution question declaring that they have been a subject of persecution. This proportion in Poland is lower at $7.1 \%$. The pattern of persecution by education is also much clearer in the Czech Republic, and the proportion of ever persecuted individuals among those with 14 or more years of education is $18.5 \%$. As one would expect among those ever persecuted political beliefs were the most commonly stated main reason for persecution (59\% in $\mathrm{CZ}$ and $37 \%$ in PL). Religion and ethnicity were also important main causes of persecution with higher proportions of the persecuted sample pointing to these reasons in Poland than in the Czech Republic. Of those who declare being victims of persecution in our samples about $14 \%$ in each country lost jobs due to persecution, while about $40 \%$ in the Czech Republic and 27\% in Poland admit experiencing discrimination at work such as denied promotions or harassment which were reflections of persecution. The structure of the SHARE data allows us to identify the jobs in which individuals were either discriminated or which they lost due to persecution, and because we know the start and end dates of these jobs their duration can be clearly identified. This is presented in Figure 1 showing the full set of job durations - separately for Poland (top panel) and the Czech Republic (bottom panel) - which have been identified as jobs in which individuals experienced persecution either through on-the-job discrimination or which they lost as a result. The figure confirms a much higher frequency of experiences of onthe-job persecution in the Czech Republic. We can also see that in the Czech Republic there is a higher number of short-term jobs in which individuals were persecuted. This may be an indication of greater severity of persecution and the resulting forced job separations. In the Czech Republic the majority of jobs in which respondents were persecuted started before mid 1960s, while in Poland most of such jobs started after that period. This reflects the history of labour relations we outlined in Section 2. As we noted, the main wave of persecution in the Czech Republic took place in the 1940s and 1950s, and for those who remained in the country it took much less severe forms later on. In Poland on the other hand, it seems that persecution at work is related principally to the developments in the 1970s and 1980s, when authorities had to deal with dissent at work and strikes related to economic difficulties and the birth of a more popular opposition movement. 
In Table 3 we can see other differences in the nature of on-the-job persecution between the two countries. The education-related pattern, for example, is much clearer in the Czech Republic than Poland. Among those with 14+ years of education who experienced persecution 39\% lost jobs as a result, and 59\% experienced the less severe forms of discrimination at work. This pattern is not as clear in Poland. In particular there are no respondents among those in the highest education group who experienced persecution and who lost their jobs in consequence. On the other hand persecution in Poland seems to be more strongly related to the number of jobs individuals have had in their careers. Those who suffered consequences of persecution at work have had on average 3.1 jobs in their career, while the average for the sample is two jobs. This pattern observed in the data shows an interesting reflection of a very different nature of functioning of the communist regimes in the two countries and their different oppressive character. In the Czech Republic the highly educated were the focus of oppression and this group was most active in the development of the opposition movement. These groups also had much more to lose in the Czech Republic where as we noted earlier returns to education were higher. In Poland the group of highly educated proportionally is much smaller, which may be why we do not observe respondents with higher education among those who lost a job due to persecution. Moreover, while the developments of the 1970s and 1980s received support of numerous highly educated individuals, the main wave of opposition and protests came from workers and labour unions, and it is these groups which would have been most likely to suffer job-related persecution.

In the third and fourth panels of Table 3 we present information on items which are the subject of our analysis. On the one hand we show sample statistics on general life experiences and overall career satisfaction (panel 3) and on the other some details concerning the characteristics of respondents' main jobs and their assessment of the quality of these job. The overall picture concerning respondents' professional careers shows a much higher proportion of individuals in Poland who are not satisfied with their job achievements $(18.2 \%$ in PL vs. $10.8 \%$ in $\mathrm{CZ})$. On the other hand a much higher proportion of those in the Czech Republic admit having experienced a major disappointment in their professional career (19.3\% in PL vs $29.3 \%$ in CZ). A significant proportion of both samples admit that their health suffered from their jobs, and about $50 \%$ of the sample in both countries admit experiencing a distinct period of stress. About $24 \%$ of Czech respondents and $40 \%$ of the Polish sample say they have experienced a distinct period of financial hardship. The last result may reflect 
the fact that at the time when many of the respondents were in their prime-age, i.e. in the 1970s and 1980s, Poland went through several periods of significant economic difficulties including shortages, rationing and high inflation.

$3.6 \%$ of respondents in the Czech sample and $1.8 \%$ of the Polish sample identify their main jobs as the jobs in which they experienced persecution, i.e. were either discriminated or fired as a reflection of persecution. It is interesting to note that a significant proportion of the respondents say that they were exposed to conflicts and disturbances in their main jobs (24.5\% in CZ and 30.3\% in PL). Similarly, less than $80 \%$ of respondents in both samples say that employees in these jobs were treated fairly. This of course may not be just a feature of work in the communist regimes, but as we shall see below this job assessment turns out to be strongly related to the experience of persecution.

\section{INSERT TABLE 4 AROUND HERE}

In Table 4 we present some information on the sample used in the analysis of the effect of on-the-job persecution on earnings presented in Section 4.3. This is a sample of multiple jobs of the individuals whose characteristics we presented in Table 3 which started prior to 1990. Among these jobs 1,598 in the Czech sample and 1,269 in the Polish sample are jobs with valid information on initial earnings. This is about $76 \%$ of all jobs starting prior to 1990 in the Czech Republic and $71 \%$ in Poland. Apart from information on some of the job characteristics Table 4 presents selected details on a measure of earnings used as the dependent variable. In the analysis the measure we use is defined as the ratio of net earnings given by respondents in the survey as their starting salary in a given job, to the mean net earnings in the country at the time when the individual was starting that specific job. This approach serves the purpose of indexing the information given by the respondents. ${ }^{11}$ As we can see in Table 4 the overall mean relative earnings in the Czech Republic in the sample of jobs we analyse is equal to 1.17, while in Poland it is about 0.71 . While one could expect the overall means to be close to one, since we are considering only initial earnings for each of the jobs, this does not necessarily have to be the case. The mean value of relative earnings will depend on the structure of wages in the country, progression of wages on the job and the duration of jobs. The pattern of earnings in both countries related to gender, education, sector and occupation seems plausible and reflects the

\footnotetext{
${ }^{11}$ The source for the official average salary statistics are Statistical Yearbooks 1949-2009 form the Polish Central Statistical Office and Statistical Yearbooks 1953-2009 from the Czech Statistical Office.
} 
information on wages reported above in Section 2. For example the relation of average relative female to male earnings is $64 \%$ in the Czech Republic and $63 \%$ in Poland, while earnings of those with the lowest level of education in the two countries represent $76 \%$ of the highest qualified in the Czech Republic and 79\% in Poland. Average earnings in the industry sector are higher than those in services or agriculture in both countries and the differences between blue and white-collar jobs reflect the low occupational premiums in the communist system. As we shall see the quality of the retrospective earnings data seems to be also verified in the multiple regressions in Section 4.3.

\section{Results}

In this Section we present the results on the extent and effects of job-related persecution under communist regimes in the Czech Republic and Poland. We begin the analysis with the most general of outcomes to which we can relate the experience of job-related persecution and look at whether it correlates with reporting of distinct periods of financial hardship and stress (Section 4.1). Subsequently we focus on specific characteristics of the main job of respondents' career (Section 4.2) and then look at the consequence of persecution on initial earnings at jobs following those in which individuals were persecuted in Section 4.3. Finally we close the analysis with an overall assessment of professional careers as reported by the respondents to show the long-lasting nature of the effects of persecution.

\subsection{Distinct Periods of Hardship}

In Tables 5 and 6 we present results on the relationship of on-the-job persecution and reporting of distinct periods of financial hardship and stress. The overpowering nature of the state's control in the two communist regimes, and in particular in the Czech Republic meant that persecution in one work-place could have long-lasting effects on the well being of individuals and their families, and thus we could expect that difficulties at work and in particular job losses could imply a higher risk of experiencing both of the above outcomes.

\section{INSERT TABLES 5 AND 6 AROUND HERE}

We look specifically at answers to two questions: "Looking back on your life, was there: 
- a distinct period during which you were under more stress compared to the rest of your life?

- a distinct period of financial hardship?

The tables report marginal effects of probit regressions, and in the case of each of the outcomes we present two specifications in which the independent variable related to persecution is either experience of job loss (columns 2 and 4) or job loss or other forms of persecution (columns 1 and 3). ${ }^{12}$ In both countries there is a much higher probability of declaring a period of stress if one experienced persecution on the job. In the case of persecution-related job loss, the marginal effect is $37.8 \%$ in the Czech Republic and $43.1 \%$ in Poland. Once other forms of discrimination are included in the independent variable, the effect is lower in the Czech Republic (20.6\%), but it is almost the same in Poland (42.2\%), suggesting that in terms of generating stressful environment the role of discrimination and job loss was almost equally strong in Poland, but that the role of job loss was far more significant in the Czech Republic. Interestingly, the results for the Czech Republic show that experience of a distinct period of stress is strongly related to education, with the respondents in the highest education group about $13 \%$ more likely to report it.

Periods of financial hardship are significantly correlated with on-the-job persecution only in the Czech Republic: the marginal effect of job loss is $37.0 \%$ while that of on-thejob discrimination and job loss is $23.8 \%$. We do not find any such effects in Poland, which may reflect either the fact that discrimination did not have direct financial consequences or that job loss due to persecution did not carry a significant financial penalty in subsequent career. Apart from that the result can also be an effect of the fact that in the 1970s and 1980s significant financial and economic hardship had very broad effects on the population as a whole. It is interesting to note that in both countries, reporting of periods of financial hardship is less likely among those with better education, but this effect is statistically significant only for those in the middleeducated group (around 9\% in the Czech Republic and 10\% in Poland). This result may relate on the one hand to the low premium to higher education which did not isolate against financial difficulties, and on the other to the more stable job situation of those with secondary education under communism.

This broad analysis of life-time experiences and on-the-job persecution lays ground for more detailed analysis in the following sections. As we saw job-related persecution

\footnotetext{
${ }^{12}$ Alternative specifications, for example including job loss and other forms of on-the-job discrimination separately as two distinct dummies, were also examined, but due to high correlation between these variables the presented ones were chosen as more clearly showing the effects of persecution.
} 
was identified as a significant factor behind the experience of stress, and in the Czech significantly correlates with the experience of financial hardship. As we shall see below these broad results find confirmation in a more specific assessment of work conditions and the effect on earnings.

\subsection{Assessment of Main Job Quality}

Results presented in this section document the relationship between assessment of quality of the main job and the experience of persecution in this specific job. Thus unlike the general questions on life experiences which we analysed above the analysis now focuses on the extent to which reported assessment of various features of respondents' main job is related to experiencing persecution in this job. Three items from the list of characteristics of the main job have been selected for the analysis as particularly interesting from the point of view of understanding the implications of persecution. The estimations examine the probability of agreeing or strongly agreeing with three following statements:

- I was exposed to recurrent conflicts and disturbances (Recurrent conflicts);

- In general, employees were treated fairly (Fair treatment);

- I received adequate support in difficult situations (Adequate support).

Since the structure of the interview allows us specifically to link the experience of persecution to a particular job the independent variable, "Discr. on job or job loss", is defined as being discriminated at or being fired from the main job. Results of the estimations are presented in Tables 7 and 8 for Czech Republic and Poland respectively, and they show marginal effects of probit regressions.

\section{INSERT TABLES 7 AND 8 AROUND HERE}

As we can see there are substantial and statistically significant effects of persecution on the assessment of the aspects of the main job quality we analyse. Those persecuted are over $27 \%$ more likely to report recurrent conflicts and unfair treatment as well as lack of support (23.8\%) in the Czech Republic. In Poland, where persecution at work was less common, the effects are even higher $(30.8 \%, 24.6 \%$ and $35.1 \%$, respectively), although insignificant in the case of fair treatment. As we saw in Figure 1 the incidence of on-the-job persecution in Poland was less frequent than in the Czech Republic, but the duration of jobs in which people were persecuted was longer. This may be behind the higher association of on-the-job discrimination with poor assessment of 
main job's quality because of weaker but potentially longer lasting discrimination and harassment. This is in line with a significant role of tertiary education in Poland on assessment of fair treatment and adequate support, which we do not find in the Czech Republic. What is particularly interesting in the analysis of the job quality assessment is the consistency of the estimated role of on-the-job persecution across the analysed outcomes for both countries. This is not the case for the other characteristics included in the regressions like gender, age or education, which depending on the analysed job characteristic are positively or negatively correlated with job quality with varying degrees of statistical significance. Given the structure of the interview which we discussed in Section 3.1 it is plausible to give these estimates a causal interpretation concluding that persecution-driven discrimination had significant effects on the quality of jobs under communism. Despite the time that has passed since these experiences, those who were subjected to persecution remember the effects it has had on the quality of their work experience.

\subsection{Effects of Persecution on Earnings}

So far the outcomes we have examined related to individual subjective assessment of their situation, either in the form of general experiences or specific evaluation of characteristics of their jobs. In this section we use the information from SHARELIFE data to look at a more objective job-related outcome which could have been affected by persecution, namely individual earnings. As we noted earlier the SHARELIFE interview asked for information on starting net earnings for all jobs in respondents' careers. We thus cannot follow the development of entire individual earnings histories and examine, for example if specific periods of persecution were reflected in pay cuts and demotions. However, by reconstructing individual work histories we can identify the jobs which followed those in which individuals experienced persecution or from which they were fired, and examine if their earnings in the following jobs were related to the prior experience of persecution. We can therefore identify the long-lasting financial consequences of persecution which may have had very significant implications for individual careers. The analysis presented in this section uses the sample of jobs presented in Table 4 and described in Section 3.2. The dependent variable is (log) relative net initial earnings (see Section 3.2 for detailed definition) in a job and the estimations identify the effect of prior experience of persecution on earnings in the following jobs. 
In Table 9 we show results of a pooled OLS regression run on available starting salaries of jobs which started prior to 1990 in our sample of employees, for which we have information on 1,598 starting salaries in the Czech Republic and 1,269 starting salaries in Poland. For each country we present two specifications of the regressions - one where the persecution-related independent variable is "Job after job loss", i.e. a dummy variable taking value 1 if a specific job is one which follows job loss due to persecution, and "Job after discr. on job or job loss", which is a dummy variable taking value 1 if a job follows the experience of either job loss or other forms of discrimination due to persecution. The dependent variables include also age, gender and education controls, as well as the time when the job started, whether it was fulltime, and additional ability/education indicators such as relative ability at math and languages at the age of 10 and the number of books at home (see Section 3.2). The results show generally plausible results as regards the usual dependent variables - they confirm significantly lower female earnings, and relatively low returns to education (we must remember here that we control for ability in the regressions).

Importantly, in the Czech sample we find strong and statistically significant negative $(-27.0 \%)$ effects of prior persecution on earnings in subsequent jobs. This is found only in the case of job loss, and is consistent with a significant stigma individuals carried once they lost their jobs due to persecution. It may relate to radical job demotions and the impossibility of finding jobs which would be in line with education and experience of the individuals. This result is particularly interesting given the strong relationship of persecution and job loss among the higher educated in the Czech Republic, and sheds light on the dramatic role persecution may have had in lives of these individuals. It is notable that the effect of persecution-driven job loss on earnings in the Czech Republic is almost as high as the education premium for higher education relative to the primary education see (Table 4). Thus the effects of persecution-related job loss on subsequent earnings correspond to a demotion of a highly educated person to a manual job. In fact there is plenty of case study historical evidence confirming this with numerous cases of demotion to such jobs as stokers or window cleaners (in the early decades of communism, the penalties were more drastic with common instances of labour camp or prison sentences). One has to bear in mind that under communism all individuals had a real obligation to work. For example, the criminal code of the Czech Republic incriminated anyone who failed to engage in a dutiful work. At the same time the state had significant control over employment and could prevent hiring so that persecuted people could be effectively prevented from 
working on a job corresponding to their education or qualification. ${ }^{13}$

Somewhat surprisingly we do not find any statistically significant effects of prior persecution on earnings in Poland, and in fact the coefficients on the persecutionrelated independent variables are positive. One must remember, however, that in the Polish sample we do not have any higher educated people who lost their jobs due to persecution, and so the key feature that drives the results in the Czech Republic is absent here. Another explanation is a higher measurement error in reporting of wages due to inflation and denomination of the currency in 1990s. ${ }^{14}$ They confirm in our view, however, that the nature of the oppressive regimes in Poland and the Czech Republic with respect to the labor market was different. While individuals could have been harassed and discriminated at work in Poland as a result of persecution and job loss was also frequently its consequence, the degree of control of the system on the individual career paths was much weaker compared to the Czech Republic. Job losses resulting from persecution in Poland to a lower extent implied a complete break down of individual careers. It seems that following these separations individuals could find jobs of similar character and of similar level of pay. This view is consistent with the nature of opposition in Poland which centred on industry workers and trade unions (like Solidarność in the 1980s) who were discriminated and harassed at work, but whose careers were broken only in exceptional circumstances which cannot be documented in a small survey like SHARE. Although the system in both countries was notionally the same, their specific implications on people's lives and the targets of government persecution were very different with much less control over people's lives in the Polish case. $^{15}$

\subsection{Career Assessment}

As we demonstrated above on-the-job discrimination in the Czech Republic and Poland is strongly related to the reporting of going through a distinct period of stress and to specific job quality assessment. In the Czech Republic persecution is also associ-

\footnotetext{
${ }^{13}$ It is difficult to find examples of estimates of the effects of persecution on earnings in the literature to compare our results to. However, it is interesting to note that the roughly $30 \%$ reduction in average earnings resulting from persecution in the Czech Republic broadly corresponds to what has been found in the US literature on race-related wage differentials. For examples of estimates of racial discrimination on earnings see: Blinder (1973), Cain (1986), Card and Krueger (1993), Oaxaca and Ransom (1994), and Altonji and Blank (1999).

${ }^{14}$ It must be noted here that the results are based on data which has been manually cleaned to correct the cases which were clearly reporting errors due to denomination and hyperinflation. These cleaning procedures are available from the authors.

${ }^{15}$ See, e.g. Naimark (1998) and Dziurok et al. (2010).
} 
ated with the experience of a distinct period of financial hardship which corresponds with the findings on substantial earnings penalties in jobs that followed a persecutionrelated job loss. We could find no evidence on such negative consequences on earnings in Poland, and this matches the results showing no significant relationship between on-the-job persecution and the reporting of financial hardship. In this section we take a closer look at the overall assessment of respondents' professional careers. We analyse the relationship of on-the-job persecution with three items of career satisfaction, by examining the probability of agreeing or strongly agreeing with the following statements:

- Considering all my efforts, I am satisfied with my work achievements (Work achievements satisfaction);

- I experienced a major disappointment in my job career (Major career disappointment);

- My health has suffered from my job (Health suffered from work).

This analysis on the one hand examines the overall "aggregated" material and non-material consequences of persecution. On the other hand it looks at the extent to which labor market experiences from the period before 1990, cast their shadow on the overall satisfaction with the professional side of people's lives.

\section{INSERT TABLES 10 AND 11 AROUND HERE}

The results of the estimations, in the form of marginal effects from probit regressions are presented in Tables 10 and 11 for the Czech Republic and Poland, respectively. As in the earlier estimations we use two measures of on-the-job persecution: job loss and discrimination on job or job loss. Interestingly the results are in line with those on the experience of financial hardship and negative consequences of persecution on earnings. Persecution implies high and statistically significant effects on overall career satisfaction in the Czech Republic but has no statistically significant effects in Poland. Marginal effects of job loss in the Czech Republic are very high. Those who lost jobs due to persecution are $65.6 \%$ less likely to express satisfaction with their work achievements and $33.7 \%$ more likely report experiencing a major disappointment in their job career. The only statistically significant effect of job loss on overall career assessment in the Polish data can be found with regard to the negative consequences of work on health $(28.4 \%)$.

No evidence of the effect of persecution in Poland on career satisfaction while consistent with earlier findings is very surprising. Once again it points to a very different 
nature of the regime and different way of the functioning of the labor markets in the two countries. These findings can be explained with less severe forms of persecution in Poland and weaker financial consequences of persecution. As we noted above this evidence suggests that in Poland the extent of breakdown of professional careers due to persecution was much lower. Persecution in Poland did not imply such heavy penalties as in the Czech Republic, and thus is not as strongly related to overall satisfaction. The degree of state's control over the labour market was much weaker, and those subjected to persecution at work, given the nature of the opposition in Poland were much more frequently industry workers. For them the financial and professional consequences of persecution, it seems, were weaker compared to the implications of persecution in the Czech Republic. It could have been easier in Poland to adjust following the experience of persecution, find work in a similar job and keep building up career satisfaction. While the Polish data suggest influence of persecution on job quality, it is not necessarily inconsistent with lack of "major career disappointment", which is the case in the Czech Republic.

\section{Conclusions}

The populations of the Czech Republic and Poland represented in the SHARE survey have lived for a substantial part of their lives under the two most oppressive regimes Europe has known. Many of the individuals in the samples experienced the horrors of World War II, and all of them for many years lived under the Soviet-controlled communist regimes. Their lives bear witness to the difficulties of these times. The analysis presented in this paper, which focused on labor market consequences of persecution in the Czech republic and Poland, shows that first-hand experience of oppression casts very long shadows and that its consequences are still present many years after the collapse of the regimes.

Individuals who were subjected to persecution at work identify its substantial negative effects on the quality of their work, and, in particular in the Czech case, show how professional careers could have been destroyed by the overpowerful communist state. In terms of career satisfaction the consequences of this influence in the Czech Republic are felt until this day. Evidence on Poland suggests a different picture, with less dramatic consequences of persecution on professional careers and less severe financial penalties experienced over the course of working life. Both the nature of the state's control in Poland, the severity of immediate consequences of persecution during 
communism as well as the fact that opposition in Poland was much more centred on industry and manual workers could serve as explanations for our findings.

The paper provides, to our knowledge, the first quantitative analysis of on-the-job persecution in two former communist countries. Job-related persecution had strong negative effects on individual welfare and work experiences. In the Czech Republic, the main channel of persecution took the form of significantly disrupted professional careers, with large (27\%) negative effects on earnings in subsequent employment. In Poland, with a different structure of the dissident groups and more liberal socioeconomic policies, persecution mainly took the form of discrimination on the job with less severe career or occupational effects. However, being subjected to persecution is still reflected in the assessment of quality of work and correlates with the experience of stressful periods in life.

The evidence in this paper certainly does not do justice to the experiences of numerous specific cases of persecution in both countries. Not only jobs, but lives were lost, opposition members were imprisoned or sent to labor camps, and in both countries there are examples of careers completely broken by the power of the communist state. The paper, however, takes a general approach and the conclusions drawn here are based on the experiences of representative samples of populations which lived under communism. It shows therefore the overall broad consequences and compares the influence of persecution as it is reflected in the experiences of these samples. The differences that we find do seem to be in line with historical evidence on the nature of the two regimes, the type of control and persecution that the two populations were subjected to and the resulting consequences persecution had on the labor market.

Many of those who suffered persecution during the years of World War II and under the subsequent communist regimes are still alive and their current conditions bear witness to the times that are thankfully over. The SHARELIFE data offers a unique opportunity to improve our understanding of the forms and consequences of persecution and discrimination prior to 1990 in Central Europe. As this paper has demonstrated, it can also be very informative about different effects of persecution suffered in the labor market and shed light on detrimental consequences of on-the-job discrimination and harassment. Experience of such treatment casts long shadows on people's lives. 


\section{Appendix}

Below we document the questions from the SHARELIFE questionnaire used in this paper.

\section{On-the-job persecution:}

Persecution resulting in a job loss is is identified in question GL024. Question GL025 identifies the lost job.

GL024 (FORCED TO STOP WORKING) Did persecution or discrimination because of [main reason of persecution] ever force you to stop working in a job?

Persecution which was reflected in on-the-job discrimination is identified in question GL026, the job by question GL027.

GL026 (EXPERIENCES IN JOB) As a consequence of persecution or discrimination because of [main reason of persecution], did you ever experience any of the following during your working life? 1. Denied promotions; 2. Assignment to a task with fewer responsibilities; 3. Working on tasks below your qualifications; 4 . Harassment by your boss or colleagues; 5 . Pay cuts; 96 . None of these.

\section{Financial hardship and period of stress:}

The distinct periods of financial hardship and stress are reported in questions GL005 and GL011.

GL005 (PERIOD OF STRESS) Looking back on your life, was there a distinct period during which you were under more stress compared to the rest of your life?

GL011 (PERIOD OF FINANCIAL HARDSHIP) Looking back on your life, was there a distinct period of financial hardship?

\section{Definition of the main job and its characteristics:}

The main job of the respondents' career is defined in question RE040.

RE040 (WHICH WAS MAIN JOB IN CAREER) Which of the jobs you have told me about was the final job of your main career or occupation? By this we mean the last job in the career or the occupation that took up most of your working life, even though you might have had other jobs afterwards'. Please code only one.

Assessment of the quality of the main job is reported in questions WQ001-013.

WQ001 (INTRODUCTION TO WORK QUALITY) I am going to read some statements people might use to describe their work. Thinking about your job as [main job], please tell me whether you strongly agree, agree, disagree or strongly disagree with each statement.

WQ006 (WORK INVOLVED CONFLICTS) I was exposed to recurrent conflicts and disturbances.

WQ011 (WORK HAD ADEQUATE SUPPORT) I received adequate support in difficult situations.

WQ013 (WORK EMPLOYEES TREATED FAIR) In general, employees were treated fairly.

\section{Starting salaries:}

The starting after-tax salary is provided in question RE021. Questions RE011-RE020 identify the job and its characteristics.

RE021 (FIRST MONTHLY WAGE IN JOB) Can you tell me, approximately, how much you were paid monthly after taxes when you started doing this job as [job title]? If you worked parttime, please tell me the actual amount that you were paid, not the full-time equivalent. 
Assessment of overall career:

WQ029 (INTRODUCTION TO SECOND WORK QUALITY) Looking back at your job career until now, please tell me whether you strongly agree, agree, disagree or strongly disagree with each statement.

WQ031 (HAD DISAPPOINTING JOB CAREER) I experienced a major disappointment in my job career.

WQ032 (SATISFIED WITH ACHIEVEMENTS) Considering all my efforts, I am satisfied with my work achievements.

WQ035 (HEALTH HAS SUFFERED AT WORK) My health has suffered from my job. 


\section{References}

Adam, J. (1984). Employment and Wage Policies in Poland, Czechoslovakia and Hungary since 1950. London, Basingstoke: The Macmillan Press Ltd.

Altonji, J. G. and R. M. Blank (1999). Race and gender in the labor market. In O. Ashenfelter and R. Layard (Eds.), Handbook of Labor Economics, Volume 3c, pp. 3143-3259. Amsterdam: Elsevier Science Publishers.

Atkinson, A. B. and J. Micklewright (1992). Economic Transformation in Eastern Europe and the Distribution of Income. Cambridge: Cambridge University Press.

Barta, M., L. Cvrcek, P. Kosicky, and V. Sommer (2009). Victims of the Occupation. The Warsaw Pact Invasion of Czechoslovakia, from August 21 to December 31, 1968. Prague: The Institute for the Study of Totalitarian Regimes.

Bayer, K. (1996). The scope of participation of Poles in the struggle for independence in the Polish State: 1939-1945. Papers of the Home Army Historical Society 1, 1-42.

Blinder, A. (1973). Wage discrimination: reduced form and structural estimates. The Journal of Human Resources 8, 436-455.

Boeri, T. and M. Keese (1992). Labour Markets And The Transition In Central And Eastern Europe. OECD Economic Studies (18).

Bohacek, R. and M. Myck (2011). Persecution in Central Europe and its Consequences on the Lives of SHARE Respondents. In A. Axel Börsch-Supan, M. Brandt, K. Hank, and M. Schröder (Eds.), The Individual and the Welfare State. Life Histories in Europe. Springer: Heidelberg.

Brainerd, E. (2000). Women in Transition: Changes in Gender Wage Differentials in Eastern Europe and the Former Soviet Union. Industrial and Labor Relations Review 53(1), 138-162.

Brzezinski, Z. (1958). The Pattern of Political Purges. Annals of the American Academy of Political and Social Science 317, 79-87.

Cain, G. G. (1986). The Economic Analysis of Labor Market Discrimination: A Survey. In O. Ashenfelter and R. Layard (Eds.), Handbook of Labor Economics, Volume 1. Amsterdam: North-Holland Press.

Card, D. and A. B. Krueger (1993). Trends in Relative Black-White Earnings Revisited. American Economic Review 83(2), 85-91.

Chodakiewicz, M. J. (2004). Between Nazis and Soviets: Occupation Politics in Poland, 1939-1947. Lexington Books.

Chodakiewicz, M. J. and D. Currell (2003). Restytucja: The Problems of Property Restitution in Poland (1939-2001). In M. J. Chodakiewicz, J. Radzilowski, and D. Tolczyk (Eds.), Poland's Transformation: A Work in Progress. Charlottesville, VA: Leopolis Press.

Ciesielski, S. (2010). Gulag. Radzieckie Obozy Koncentracyjne 1918-1953. Warsaw: Institut Pamieci Narodowej.

Ciesielski, S., W. Materski, and A. Paczkowski (2002). Soviet repressions against Poles and Polish citizens. Warsaw.

Ciolek, E. (2010). Solidarnosc. August 1980 - August 1989. Warsaw: Institut Pamieci Narodowej.

Courtois, S., N. Werth, J.-L. Panne, B. K. Paczkowski, Andrzej, and J.-L. Margolin (1999). The Black Book of Communism: Crimes, Terror, Repression. Cambridge, MA: Harvard University Press.

CSU (2010). Cesky Statisticky Urad: Obyvatelstvo. Praha: CSU.

Davies, N. (2005). God's Playground: 1795 to the present. New York: Columbia University Press.

Dziurok, A., M. Galerzowski, L. Kaminski, and F. Musial (2010). Od Niepodleglosci do Niepodleglosci. Historia Polski 1918-1989. Warsaw: Institut Pamieci Narodowej.

Eberhardt, P. (2006). Political Migrations In Poland 1939-1948. Warsaw.

Gebauer, F., K. Kaplan, F. Koudelka, and R. Vyhnalek (1993). Judicial Persecution of a Political Nature in Czechoslovakia 1948-1989: A Statistical Survey. Prague: Institute for Contemporary History of the Czech Academy of Sciences.

Granville, J. (2001). Hungarian and Polish Reactions to the Events of 1956: New Archival Evidence. Europe-Asia Studies 53(7), 1051-1076. 
Gross, J. T. (1979). Polish Society under German Occupation: The Generalgouvernement, 19391944. Princeton: Princeton University Press.

Gross, J. T. (1988). Revolution from Abroad. The Soviet Conquest of Poland's Western Ukraine and Western Byelorussia. Princeton, NJ: Guilford.

GUS (1994). Glowny Urzad Statystyczny: Historia Polski w Liczbach. Warsaw: GUS.

Jackman, R. and M. Rutkowski (1994). Labour markets : wages and employment. In N. Barr (Ed.), Labor markets and social policy in Central and Eastern Europe : the transition and beyond. New York, N.Y.: Oxford University Press.

Kaplan, K. (1992). The Deceased in Prisons and Death Sentences. Prague: Institute for Contemporary History of the Czech Academy of Sciences.

Kaplan, K. (1994). On Political Trials in Czechoslovakia 1948-1954: Documentation of the Czechoslovak Communist Party Central Committee Commission for Rehabilitation 1968. Prague: Institute for Contemporary History of the Czech Academy of Sciences.

Kaplan, K. and P. Palecek (2001). Communist Regime and Political Trials in Czechoslovakia. Brno: Barrister and Principal.

Kobuszewski, B., P. Matusak, and T. Rawski (1988). Polish resistance movement 1939-1945. Warsaw.

Luczak, C. (1993). Poland and the Poles in World War II. Poznan: Institute for Contemporary History of the Czech Academy of Sciences.

Lukas, R. C. (2001). Forgotten Holocaust: The Poles Under German Occupation 1939-1944. Hippocrene Books.

Malcher, G. C. (1993). Blank Pages: Soviet Genocide Against the Polish People. Pyrford Press.

Materski, W. and T. Szarota (2009). Polska 1939-1945. Straty osobowe $i$ ofiary represji pod dwiema okupacjami. Warsaw: Institut Pamieci Narodowej.

Naimark, N. (1998). The Establishment of Communist Regimes in Eastern Europe, 1944-1949. Westview Press.

Nesporova, A. (1999). Employment and labour market policies in transition economies. International Labour Organization.

Oaxaca, R. L. and M. R. Ransom (1994). On discrimination and the decomposition of wage differentials. Journal of Econometrics 61, 5-21.

Persak, K. and L. Kaminski (2005). A Handbook of the Communist Security Apparatus in East Central Europe 1944-1989. Warsaw: Institut Pamieci Narodowej.

Ray, G. F. (1991). Innovation and productivity in Eastern Europe: an International Comparison. National Institute Economic Review, 75-83.

Rummel, R. J. (1994). Power, Genocide and Mass Murder. Journal of Peace Research 31(1), 1-10.

Rutkowski, J. (1996a). Changes in the wage structure during economic transition in Central and Eastern Europe. World Bank Technical Paper (336).

Rutkowski, J. (1996b). High skills pay off: the changing wage structure during economic transition in Poland. Economics of Transition 4(1), 89-112.

Snyder, T. (2010). Bloodlands: Europe between Hitler and Stalin. New York: Basic Books.

Svejnar, J. (1999). Labor Markets In The Transitional Central And East European Economies. In O. Ashenfelter and R. Layard (Eds.), Handbook of Labor Economics, Volume 3, pp. 2809-2857. Amsterdam: Elsevier Science Publishers.

Wheatcroft, S. (1996). The Scale and Nature of German and Soviet Repression and Mass Killings: 1930-1945. Europe-Asia Studies 48(8), 1319-1353. 
Table 1: Persecution in the Czech Lands 1939-1989

\begin{tabular}{lr}
\hline \multicolumn{2}{c}{ World War II: 1939-1945 } \\
\hline Majority Population 1939 & $7,255,500$ \\
\hline Arrests & 115,000 \\
Forced Labor & 420,000 \\
Deported to Gulag & 7,000 \\
Expelled/Relocated & $150-250,000$ \\
\hline Deaths: & \\
Concentration Camps & 20,000 \\
Other* & 21,500 \\
Forced Labor & 3,500 \\
Gulag & 4,000 \\
Civilian** & 12,000 \\
Total & 61,000 \\
& \\
& \\
\hline Population 1948 & \\
\hline Arrests & \\
Corrective Labor Camp & 205,000 \\
Penal Labor Camp & 70,000 \\
Military & 20,000 \\
Clergy & 60,000 \\
Emigration & 10,300 \\
\hline Deaths: & 270,000 \\
\hline Executed & \\
Prison & \\
Border & 5,048 \\
Total & \\
\hline \hline
\end{tabular}

Notes: Total population in 1939, including Germans: 10,480,000. Excludes persecution and population of Slovakia and Ruthinia (parts of Czechoslovakia in 1938), victims of the Holocaust, and deaths of those serving in foreign armies (Western and Eastern fronts, RAF) and those in exile, namely the German population expelled after the end of World War II. *Deaths during Prague upraising, resistance victims and other persecution. ${ }^{* *}$ Victims of air raids.

Sources: The Office for the Documentation and the Investigation of the Crimes of Communism, The Institute for the Study of Totalitarian Regimes, Courtois et al. (1999), CSU (2010), Barta et al. (2009), Gebauer et al. (1993), Kaplan (1992), Kaplan (1994), Kaplan and Palecek (2001), Naimark (1998). 
Table 2: Persecution in Poland 1939-1989

\begin{tabular}{|c|c|c|}
\hline \multicolumn{3}{|c|}{ World War II 1939-1944 and Period 1944-1956 } \\
\hline $\begin{array}{l}\text { Population } 1939 \text { Total } \\
\text { Population } 1939 \text { Post-War Bord } \\
\text { Population } 1946 \\
\text { Net Emigration 1946-1956 }\end{array}$ & $\mathrm{rs}^{\dagger}$ & $\begin{array}{r}\text { Total } \\
35,339,000 \\
32,338,000 \\
23,929,000 \\
703,000\end{array}$ \\
\hline Area under control : & Nazi Germany & Soviet Union \\
\hline Population 1939 & $22,140,000$ & $13,199,000$ \\
\hline $\begin{array}{l}\text { Arrests } \\
\text { Conscripted to the Army } \\
\text { Forced Labor } \\
\text { Relocated/Gulag }\end{array}$ & $\begin{array}{r}250,000 \\
1,500,000 \\
2,478,000 \\
\end{array}$ & $\begin{array}{l}500,000 \\
210,000\end{array}$ \\
\hline $\begin{array}{l}\text { Deaths: } \\
\text { Military/POW* } \\
\text { Concentration Camps/Gulag } \\
\text { Forced Labor } \\
\text { Genocide in Ukraine } \\
\text { Civilian** } \\
\text { Resistance movement } \\
\text { Total }\end{array}$ & $\begin{array}{r}460,000 \\
500,000 \\
274,000 \\
\\
365,000 \\
103,000 \\
1,750,000\end{array}$ & $\begin{array}{r}160,000 \\
591,000 \\
\\
200,000 \\
50,000 \\
65,000 \\
1,000,000\end{array}$ \\
\hline \multicolumn{3}{|c|}{ Period 1956-1989 } \\
\hline $\begin{array}{l}\text { Population } 1956 \ddagger \\
\text { Net Emigration } 1957-1989\end{array}$ & & $\begin{array}{r}28,080,000 \\
746,, 000 \\
\end{array}$ \\
\hline $\begin{array}{l}1956 \text { Poznan } \\
1970 \text { Baltic coast } \\
1981 \text { Martial Law }\end{array}$ & $\begin{array}{r}\text { Wounded } \\
500 \\
1,165\end{array}$ & $\begin{array}{l}2,989 \\
9,736\end{array}$ \\
\hline
\end{tabular}

Notes: All numbers refer to the post-war Polish borders.

$\dagger$ Composed of 20,665,000 Poles, 8,583,000 Germans, 2,254,000 Jews, 657,000 Ukrainians, 141,000 Belorussians and 47,000 other nationalities. $\ddagger$ In 1950 , after massive emigration and immigration, the total population was 25,008,000, composed of 24,448,000 Poles, 170,000 Germans, 50,000 Jews, 150,000 Ukrainians, 160,000 Belorussians and 30,000 other nationalities. ${ }^{*}$ Includes 21,857 victims of the Katyn massacres. ** Includes 180-200,000 victims of the Warsaw uprising. Does not include victims of the Holocaust.

Persecution after 1956: registered victims, estimates tenfold. Sources: Institut Pamieci Narodowej, Bayer (1996), Chodakiewicz (2004), Chodakiewicz and Currell (2003), Ciesielski (2010), Ciesielski et al. (2002), Ciolek (2010), Courtois et al. (1999), Davies (2005), Dziurok et al. (2010), Eberhardt (2006), Granville (2001), Gross (1979), Gross (1988), GUS (1994), Kobuszewski et al. (1988), Lukas (2001), Luczak (1993), Malcher (1993), Materski and Szarota (2009), Naimark (1998), Persak and Kaminski (2005), Snyder (2010), Wheatcroft (1996). 
Table 3: Sample statistics - individuals in the estimation sample

\begin{tabular}{|c|c|c|c|c|}
\hline & \multicolumn{2}{|c|}{ Czech Republic } & \multicolumn{2}{|c|}{ Poland } \\
\hline & Mean & St. dev. & Mean & St. dev. \\
\hline Number of individuals & \multicolumn{2}{|c|}{1126} & \multicolumn{2}{|c|}{869} \\
\hline Age at SHARE wave 3 & 68.91 & $(8.19)$ & 65.26 & $(8.86)$ \\
\hline Female & 0.640 & $(0.480)$ & 0.551 & $(0.498)$ \\
\hline Years of education: $10-13$ & 0.623 & $(0.485)$ & 0.468 & $(0.499)$ \\
\hline Years of education: $14+$ & 0.194 & $(0.396)$ & 0.089 & $(0.285)$ \\
\hline At age 10: much better in math & 0.122 & $(0.328)$ & 0.089 & $(0.285)$ \\
\hline At age 10: much better in language & 0.097 & $(0.297)$ & 0.100 & $(0.300)$ \\
\hline At age 10: books at home - up to one shelf & 0.439 & $(0.496)$ & 0.799 & $(0.401)$ \\
\hline \multicolumn{5}{|l|}{ Persecution: } \\
\hline Ever persecuted & 0.137 & $(0.344)$ & 0.071 & $(0.257)$ \\
\hline Years of education $<10$ & 0.093 & $(0.292)$ & 0.059 & $(0.236)$ \\
\hline Years of education $10-13$ & 0.134 & $(0.341)$ & 0.085 & $(0.279)$ \\
\hline Years of education $14+$ & 0.185 & $(0.390)$ & 0.060 & $(0.240)$ \\
\hline \multicolumn{5}{|l|}{ Conditional on ever being persecuted: } \\
\hline \multicolumn{5}{|l|}{ Main reason for persecution: } \\
\hline Political beliefs & 0.586 & $(0.495)$ & 0.372 & $(0.487)$ \\
\hline Background & 0.132 & $(0.340)$ & 0.142 & $(0.352)$ \\
\hline Religion & 0.115 & $(0.320)$ & 0.165 & $(0.374)$ \\
\hline Ethnicity & 0.061 & $(0.240)$ & 0.177 & $(0.384)$ \\
\hline Other & 0.106 & $(0.309)$ & 0.144 & $(0.353)$ \\
\hline Ever lost job due to persecution: & 0.138 & $(0.346)$ & 0.143 & $(0.352)$ \\
\hline Years of education: $<10$ & 0.049 & $(0.221)$ & 0.187 & $(0.398)$ \\
\hline Years of education: $10-13$ & 0.047 & $(0.212)$ & 0.133 & $(0.344)$ \\
\hline Years of education: $14+$ & 0.393 & $(0.497)$ & 0.000 & $(0.000)$ \\
\hline Ever discriminated at work due to persecution: & 0.396 & $(0.491)$ & 0.274 & $(0.450)$ \\
\hline Years of education: $<10$ & 0.181 & $(0.394)$ & 0.317 & $(0.475)$ \\
\hline Years of education: $10-13$ & 0.357 & $(0.482)$ & 0.226 & $(0.425)$ \\
\hline Years of education: $14+$ & 0.588 & $(0.501)$ & 0.416 & $(0.540)$ \\
\hline Number of jobs & 2.237 & $(1.328)$ & 2.013 & $(1.284)$ \\
\hline If ever persecuted & 2.559 & $(1.510)$ & 2.404 & $(2.194)$ \\
\hline If persecuted with job consequences & 2.354 & $(1.616)$ & 3.080 & $(3.536)$ \\
\hline \multicolumn{5}{|l|}{ Life experiences and career assessment: } \\
\hline Not satisfied with job achievements & 0.108 & $(0.311)$ & 0.182 & $(0.386)$ \\
\hline Experienced a major disappointment in job career & 0.293 & $(0.455)$ & 0.193 & $(0.395)$ \\
\hline Health suffered from job & 0.354 & $(0.479)$ & 0.542 & $(0.498)$ \\
\hline Experienced distinct period of stress & 0.464 & $(0.499)$ & 0.504 & $(0.500)$ \\
\hline Experienced distinct period of financial hardship & 0.236 & $(0.425)$ & 0.402 & $(0.491)$ \\
\hline \multicolumn{5}{|l|}{ Characteristics of the main job: } \\
\hline Year job started & 1963.90 & $(10.06)$ & 1968.17 & $(9.98)$ \\
\hline Year job ended & 1991.97 & $(9.68)$ & 1992.31 & $(8.93)$ \\
\hline Full time job & 0.969 & $(0.173)$ & 0.987 & $(0.112)$ \\
\hline Exposed to conflicts and disturbances & 0.245 & $(0.430)$ & 0.303 & $(0.460)$ \\
\hline Employees were treated fairly & 0.795 & $(0.404)$ & 0.772 & $(0.420)$ \\
\hline Adequate support in difficulties & 0.762 & $(0.426)$ & 0.654 & $(0.476)$ \\
\hline Discriminated or fired due to persecution & 0.036 & $(0.186)$ & 0.018 & $(0.132)$ \\
\hline If main job blue collar & 0.029 & $(0.167)$ & 0.010 & $(0.102)$ \\
\hline If main job white collar & 0.043 & $(0.202)$ & 0.037 & $(0.190)$ \\
\hline
\end{tabular}

Source: Authors' calculations using SHARELIFE data. 
Table 4: Sample statistics - jobs in the wage estimation sample

\begin{tabular}{|c|c|c|c|c|}
\hline & \multicolumn{2}{|c|}{ Czech Republic } & \multicolumn{2}{|c|}{ Poland } \\
\hline & Mean & St. dev. & Mean & St. dev. \\
\hline Number of jobs with salary information & \multicolumn{2}{|c|}{1598} & \multicolumn{2}{|c|}{1269} \\
\hline Year job started & 1966.67 & $(9.16)$ & 1967.76 & $(8.98)$ \\
\hline Year job ended & 1982.19 & $(14.43)$ & 1982.12 & $(14.62)$ \\
\hline Job after being fired & 0.008 & $(0.089)$ & 0.011 & $(0.106)$ \\
\hline Job after being fired or discriminated & 0.014 & $(0.118)$ & 0.012 & $(0.108)$ \\
\hline Full time job & 0.958 & $(0.200)$ & 0.974 & $(0.159)$ \\
\hline \multicolumn{5}{|l|}{ Mean relative earnings: } \\
\hline All & 1.167 & $(0.877)$ & 0.712 & $(0.630)$ \\
\hline \multicolumn{5}{|l|}{ By gender: } \\
\hline Males & 1.528 & $(1.143)$ & 0.870 & $(0.682)$ \\
\hline Females & 0.974 & $(0.613)$ & 0.544 & $(0.521)$ \\
\hline \multicolumn{5}{|l|}{ By education: } \\
\hline Years of education $<10$ & 1.000 & $(0.751)$ & 0.672 & $(0.613)$ \\
\hline Years of education $10-13$ & 1.154 & $(0.877)$ & 0.715 & $(0.589)$ \\
\hline Years of education $14+$ & 1.311 & $(0.930)$ & 0.848 & $(0.850)$ \\
\hline \multicolumn{5}{|l|}{ By sector: } \\
\hline Agriculture & 0.971 & $(0.558)$ & 0.651 & $(0.489)$ \\
\hline Industry & 1.200 & $(0.840)$ & 0.808 & $(0.730)$ \\
\hline Services & 1.163 & $(0.939)$ & 0.622 & $(0.525)$ \\
\hline \multicolumn{5}{|l|}{ By occupation: } \\
\hline Blue collar & 1.138 & $(0.866)$ & 0.673 & $(0.619)$ \\
\hline White collar & 1.193 & $(0.887)$ & 0.805 & $(0.651)$ \\
\hline Proportion of jobs with earnings information: & 0.761 & $(0.426)$ & 0.709 & $(0.454)$ \\
\hline
\end{tabular}

Source: Authors' calculations using SHARELIFE data.

Notes: Of jobs recorded for the sample the proportion in which we have "Proportion of jobs with salary information" available for $76 \%$ of jobs in the Czech Republic and $71 \%$ for Poland for the sample of individuals used in the analysis. 
Table 5: Distinct periods of hardship — the Czech Republic

\begin{tabular}{|c|c|c|c|c|}
\hline & \multicolumn{2}{|c|}{$\begin{array}{l}\text { Distinct period of } \\
\text { financial hardship }\end{array}$} & \multicolumn{2}{|c|}{$\begin{array}{c}\text { Distinct period of } \\
\text { stress }\end{array}$} \\
\hline & $(1)$ & $(2)$ & $(3)$ & $(4)$ \\
\hline Job loss (d) & & $\begin{array}{l}0.370^{* *} \\
(0.153)\end{array}$ & & $\begin{array}{c}0.378^{* * *} \\
(0.100)\end{array}$ \\
\hline Discr. on job or job loss (d) & $\begin{array}{c}0.238^{* *} \\
(0.097)\end{array}$ & & $\begin{array}{c}0.206^{* *} \\
(0.087)\end{array}$ & \\
\hline Age & $\begin{array}{c}-0.006^{* *} \\
(0.003)\end{array}$ & $\begin{array}{c}-0.006^{* *} \\
(0.003)\end{array}$ & $\begin{array}{c}-0.007^{* * *} \\
(0.003)\end{array}$ & $\begin{array}{c}-0.007^{* * * *} \\
(0.003)\end{array}$ \\
\hline Female (d) & $\begin{array}{c}0.046 \\
(0.040)\end{array}$ & $\begin{array}{c}0.041 \\
(0.039)\end{array}$ & $\begin{array}{c}0.086^{* *} \\
(0.043)\end{array}$ & $\begin{array}{l}0.083^{*} \\
(0.043)\end{array}$ \\
\hline Education 10-13 (d) & $\begin{array}{c}-0.094^{* *} \\
(0.043)\end{array}$ & $\begin{array}{c}-0.087^{* *} \\
(0.043)\end{array}$ & $\begin{array}{c}0.042 \\
(0.051)\end{array}$ & $\begin{array}{c}0.047 \\
(0.050)\end{array}$ \\
\hline Education $14+(\mathrm{d})$ & $\begin{array}{l}-0.051 \\
(0.055)\end{array}$ & $\begin{array}{l}-0.052 \\
(0.055)\end{array}$ & $\begin{array}{c}0.134^{* *} \\
(0.067)\end{array}$ & $\begin{array}{c}0.131^{* *} \\
(0.067)\end{array}$ \\
\hline Pseudo $R^{2}$ & 0.029 & 0.026 & 0.025 & 0.026 \\
\hline Observations & 1126 & 1126 & 1126 & 1126 \\
\hline
\end{tabular}

Source: Authors' calculations using SHARELIFE data.

Notes: Marginal effects; robust standard errors in parentheses. ${ }^{*} p<0.1$, ${ }^{* *} p<0.05,{ }^{* * *} p<0.01$. (d) for discrete change of dummy variable from 0 to 1 .

Table 6: Distinct periods of hardship — Poland

\begin{tabular}{lccccc}
\hline \hline & \multicolumn{2}{c}{$\begin{array}{c}\text { Distinct period of } \\
\text { financial hardship }\end{array}$} & & \multicolumn{2}{c}{$\begin{array}{c}\text { Distinct period of } \\
\text { stress }\end{array}$} \\
\cline { 2 - 3 } \cline { 5 - 6 } & $(1)$ & $(2)$ & & $(3)$ & $(4)$ \\
\hline Job loss $(d)$ & & -0.033 & & $0.431^{* * *}$ \\
& & $(0.210)$ & & $(0.076)$ \\
Discr. on job or job loss $(\mathrm{d})$ & 0.131 & & & $0.422^{* * *}$ & \\
& $(0.129)$ & & & $(0.053)$ \\
Age & $-0.009^{* * *}$ & $-0.009^{* * *}$ & & $-0.005^{* *}$ & $-0.005^{* *}$ \\
& $(0.003)$ & $(0.003)$ & & $(0.002)$ & $(0.002)$ \\
Female (d) & 0.047 & 0.048 & & $0.111^{* * *}$ & $0.114^{* * *}$ \\
& $(0.038)$ & $(0.038)$ & & $(0.038)$ & $(0.038)$ \\
Education 10-13 (d) & $-0.105^{* *}$ & $-0.102^{* *}$ & & 0.060 & 0.063 \\
Education 14+ (d) & $(0.042)$ & $(0.042)$ & & $(0.042)$ & $(0.042)$ \\
& -0.114 & -0.112 & & 0.060 & 0.067 \\
& $(0.073)$ & $(0.073)$ & & $(0.073)$ & $(0.072)$ \\
\hline Pseudo $R^{2}$ & 0.023 & 0.022 & & 0.032 & 0.025 \\
Observations & 869 & 869 & & 869 & 869 \\
\hline \hline
\end{tabular}

Source: Authors' calculations using SHARELIFE data.

Notes: Marginal effects; robust standard errors in parentheses. ${ }^{*} p<0.1$, ** $p<0.05, * * * p<0.01$. (d) for discrete change of dummy variable from 0 to 1 . 
Table 7: Assessment of main job quality — the Czech Republic

\begin{tabular}{lccc}
\hline \hline & $\begin{array}{c}\text { Recurrent } \\
\text { conflicts } \\
(1)\end{array}$ & $\begin{array}{c}\text { Fair } \\
\text { treatment } \\
(2)\end{array}$ & $\begin{array}{c}\text { Adequate } \\
\text { support } \\
(3)\end{array}$ \\
\hline Discr. on job or job loss (d) & $0.271^{* *}$ & $-0.273^{* *}$ & $-0.238^{*}$ \\
Year job started & $(0.118)$ & $(0.124)$ & $(0.127)$ \\
& -0.003 & -0.000 & 0.002 \\
Year job ended & $(0.002)$ & $(0.002)$ & $(0.002)$ \\
& -0.003 & 0.001 & 0.004 \\
Full time job (d) & $(0.002)$ & $(0.002)$ & $(0.002)$ \\
& $0.166^{* * *}$ & -0.080 & -0.099 \\
Age & $(0.052)$ & $(0.093)$ & $(0.069)$ \\
Female $(d)$ & $-0.008^{* *}$ & 0.005 & $0.008^{* *}$ \\
Education 10-13 (d) & $(0.003)$ & $(0.003)$ & $(0.003)$ \\
Education 14+ (d) & $-0.123^{* * *}$ & 0.033 & 0.001 \\
& $(0.038)$ & $(0.038)$ & $(0.038)$ \\
& 0.007 & -0.008 & 0.032 \\
Pseudo $R^{2}$ & $(0.041)$ & $(0.038)$ & $(0.041)$ \\
Observations & 0.050 & -0.013 & 0.020 \\
\hline \hline
\end{tabular}

Source: Authors' calculations using SHARELIFE data.

Notes: Marginal effects; robust standard errors in parentheses. ${ }^{*} p<0.1$, ** $p<0.05$, *** $p<0.01$. (d) for discrete change of dummy variable from 0 to 1.

Table 8: Assessment of main job quality — Poland

\begin{tabular}{lccc}
\hline \hline & $\begin{array}{c}\text { Recurrent } \\
\text { conflicts } \\
(1)\end{array}$ & $\begin{array}{c}\text { Fair } \\
\text { treatment } \\
(2)\end{array}$ & $\begin{array}{c}\text { Adequate } \\
\text { support } \\
(3)\end{array}$ \\
\hline Discr. on job or job loss (d) & $0.308^{* *}$ & -0.246 & $-0.351^{* *}$ \\
Year job started & $(0.150)$ & $(0.153)$ & $(0.138)$ \\
& $0.005^{* *}$ & -0.003 & $-0.008^{* * *}$ \\
Year job ended & $(0.002)$ & $(0.002)$ & $(0.003)$ \\
Full time job (d) & 0.003 & -0.002 & 0.002 \\
Age & $(0.002)$ & $(0.002)$ & $(0.003)$ \\
Female (d) & -0.171 & 0.196 & $0.359^{* *}$ \\
Education 10-13 (d) & $(0.167)$ & $(0.177)$ & $(0.148)$ \\
& $0.005^{*}$ & 0.002 & $-0.006^{*}$ \\
Education $14+(\mathrm{d})$ & $(0.003)$ & $(0.003)$ & $(0.003)$ \\
& $-0.064^{*}$ & $-0.076 * *$ & -0.033 \\
& $(0.036)$ & $(0.032)$ & $(0.037)$ \\
& 0.006 & 0.035 & 0.019 \\
Pseudo $R^{2}$ & $(0.039)$ & $(0.034)$ & $(0.041)$ \\
Observations & -0.076 & $0.123^{* * *}$ & $0.108^{*}$ \\
\hline \hline
\end{tabular}

Source: Authors' calculations using SHARELIFE data.

Notes: Marginal effects; robust standard errors in parentheses. ${ }^{*} p<0.1$, ** $p<0.05,{ }^{* * *} p<0.01$. (d) for discrete change of dummy variable from 0 to 1 . 
Table 9: Effects of persecution on earnings

\begin{tabular}{|c|c|c|c|c|}
\hline \multirow[b]{2}{*}{ Dependent variable: log relative wage } & \multicolumn{2}{|c|}{ Czech Republic } & \multicolumn{2}{|c|}{ Poland } \\
\hline & $(1)$ & $(2)$ & $(3)$ & $(4)$ \\
\hline \multirow[t]{2}{*}{ Job after job loss } & & $-0.270^{* * *}$ & & 0.223 \\
\hline & & $(0.101)$ & & $(0.172)$ \\
\hline \multirow[t]{2}{*}{ Job after discr. on job or job loss } & -0.155 & & 0.203 & \\
\hline & $(0.101)$ & & $(0.165)$ & \\
\hline \multirow[t]{2}{*}{ Year job started } & $-2.349^{* *}$ & $-2.380 * *$ & $-1.905^{*}$ & -1.921 \\
\hline & $(0.995)$ & $(0.997)$ & $(1.029)$ & $(1.031)^{*}$ \\
\hline \multirow[t]{2}{*}{ Year job started sq. } & $0.600^{* *}$ & $0.608^{* *}$ & $0.485^{*}$ & $0.489^{*}$ \\
\hline & $(0.253)$ & $(0.253)$ & $(0.261)$ & $(0.262)$ \\
\hline \multirow[t]{2}{*}{ Full time job } & $0.376^{* * *}$ & $0.375^{* * *}$ & $0.359^{*}$ & $0.359^{*}$ \\
\hline & $(0.120)$ & $(0.120)$ & $(0.190)$ & $(0.190)$ \\
\hline \multirow[t]{2}{*}{ Age } & $0.023^{* * *}$ & $0.023^{* * *}$ & $0.024^{* * *}$ & $0.024^{* * *}$ \\
\hline & $(0.003)$ & $(0.003)$ & $(0.005)$ & $(0.005)$ \\
\hline \multirow[t]{2}{*}{ Female } & $-0.340 * * *$ & $-0.341^{* * *}$ & $-0.505^{* * *}$ & $-0.505^{* * *}$ \\
\hline & $(0.037)$ & $(0.037)$ & $(0.048)$ & $(0.048)$ \\
\hline \multirow[t]{2}{*}{ Education 10-13 } & $0.100^{* *}$ & $0.099 * *$ & $0.169^{* * *}$ & $0.169^{* * *}$ \\
\hline & $(0.043)$ & $(0.043)$ & $(0.047)$ & $(0.047)$ \\
\hline \multirow[t]{2}{*}{ Education $14+$} & $0.129^{* *}$ & $0.132^{* *}$ & 0.145 & 0.145 \\
\hline & $(0.052)$ & $(0.052)$ & $(0.106)$ & $(0.106)$ \\
\hline \multirow[t]{2}{*}{ Age 10: maths+ } & $-0.150^{* *}$ & $-0.153^{* *}$ & $0.214^{* * *}$ & $0.213^{* * *}$ \\
\hline & $(0.059)$ & $(0.059)$ & $(0.077)$ & $(0.077)$ \\
\hline \multirow[t]{2}{*}{ Age 10: language+ } & $0.107^{*}$ & $0.106^{*}$ & $0.214^{* * *}$ & $0.214^{* * *}$ \\
\hline & $(0.058)$ & $(0.058)$ & $(0.083)$ & $(0.083)$ \\
\hline \multirow[t]{2}{*}{ Age 10: no books } & 0.056 & 0.057 & $-0.129^{* *}$ & $-0.128^{* *}$ \\
\hline & $(0.035)$ & $(0.035)$ & $(0.061)$ & $(0.061)$ \\
\hline \multirow[t]{2}{*}{ Constant } & $2298.114^{* *}$ & $2328.228^{* *}$ & $1869.530^{*}$ & $1884.479 *$ \\
\hline & $(979.336)$ & $(981.206)$ & $(1013.524)$ & $(1015.196)$ \\
\hline$R^{2}$ & 0.261 & 0.262 & 0.210 & 0.210 \\
\hline Observations & 1598 & 1598 & 1269 & 1269 \\
\hline
\end{tabular}

Source: Authors' calculations using SHARELIFE data.

Notes: Robust standard errors in parentheses. ${ }^{*} p<0.1$, ** $p<0.05$, *** $p<0.01$. 
Table 10: Career assessment — the Czech Republic

\begin{tabular}{|c|c|c|c|c|c|c|}
\hline & \multicolumn{2}{|c|}{$\begin{array}{l}\text { Work achievement } \\
\text { satisfaction }\end{array}$} & \multicolumn{2}{|c|}{$\begin{array}{c}\text { Major career } \\
\text { disappointment }\end{array}$} & \multicolumn{2}{|c|}{$\begin{array}{l}\text { Health suffered } \\
\text { from work }\end{array}$} \\
\hline & $(1)$ & $(2)$ & $(3)$ & $(4)$ & $(5)$ & $(6)$ \\
\hline Job loss (d) & & $\begin{array}{c}-0.656^{* * *} \\
(0.135)\end{array}$ & & $\begin{array}{c}0.337^{* *} \\
(0.157)\end{array}$ & & $\begin{array}{c}0.132 \\
(0.172)\end{array}$ \\
\hline Discr. on job or job loss (d) & $\begin{array}{c}-0.261^{* *} \\
(0.102)\end{array}$ & & $\begin{array}{c}0.225^{* *} \\
(0.097)\end{array}$ & & $\begin{array}{c}0.160 \\
(0.099)\end{array}$ & \\
\hline Age & $\begin{array}{c}0.003^{* *} \\
(0.001)\end{array}$ & $\begin{array}{c}0.003^{* *} \\
(0.001)\end{array}$ & $\begin{array}{c}-0.011^{* * *} \\
(0.002)\end{array}$ & $\begin{array}{c}-0.011^{* * *} \\
(0.002)\end{array}$ & $\begin{array}{c}-0.008^{* * *} \\
(0.002)\end{array}$ & $\begin{array}{c}-0.008^{* * * *} \\
(0.002)\end{array}$ \\
\hline Female (d) & $\begin{array}{c}-0.053^{* *} \\
(0.022)\end{array}$ & $\begin{array}{c}-0.050 * * \\
(0.021)\end{array}$ & $\begin{array}{c}-0.079^{* *} \\
(0.040)\end{array}$ & $\begin{array}{c}-0.085^{* *} \\
(0.040)\end{array}$ & $\begin{array}{c}-0.082^{* *} \\
(0.041)\end{array}$ & $\begin{array}{c}-0.087^{* *} \\
(0.041)\end{array}$ \\
\hline Education 10-13 (d) & $\begin{array}{c}0.057^{* *} \\
(0.026)\end{array}$ & $\begin{array}{c}0.050^{* *} \\
(0.025)\end{array}$ & $\begin{array}{l}-0.007 \\
(0.043)\end{array}$ & $\begin{array}{l}-0.001 \\
(0.043)\end{array}$ & $\begin{array}{c}-0.160^{* * *} \\
(0.048)\end{array}$ & $\begin{array}{c}-0.156^{* * *} \\
(0.047)\end{array}$ \\
\hline Education $14+(\mathrm{d})$ & $\begin{array}{c}0.096^{* * *} \\
(0.018)\end{array}$ & $\begin{array}{c}0.107^{* * * *} \\
(0.017)\end{array}$ & $\begin{array}{c}0.002 \\
(0.062)\end{array}$ & $\begin{array}{c}0.003 \\
(0.063)\end{array}$ & $\begin{array}{c}-0.233^{* * *} \\
(0.048)\end{array}$ & $\begin{array}{c}-0.226^{* * *} \\
(0.049)\end{array}$ \\
\hline Pseudo $R^{2}$ & 0.069 & 0.091 & 0.045 & 0.042 & 0.035 & 0.032 \\
\hline Observations & 1126 & 1126 & 1126 & 1126 & 1126 & 1126 \\
\hline
\end{tabular}

Source: Authors' calculations using SHARELIFE data.

Notes: Marginal effects; robust standard errors in parentheses. ${ }^{*} p<0.1,{ }^{* *} p<0.05,{ }^{* * *} p<0.01$.

(d) for discrete change of dummy variable from 0 to 1 .

Table 11: Career assessment — Poland

\begin{tabular}{|c|c|c|c|c|c|c|}
\hline & \multicolumn{2}{|c|}{$\begin{array}{l}\text { Work achievement } \\
\text { satisfaction }\end{array}$} & \multicolumn{2}{|c|}{$\begin{array}{c}\text { Major career } \\
\text { disappointment }\end{array}$} & \multicolumn{2}{|c|}{$\begin{array}{l}\text { Health suffered } \\
\text { from work }\end{array}$} \\
\hline & $(1)$ & $(2)$ & $(3)$ & $(4)$ & $(5)$ & $(6)$ \\
\hline Job loss (d) & & $\begin{array}{c}0.074 \\
(0.103)\end{array}$ & & $\begin{array}{c}0.358 \\
(0.221)\end{array}$ & & $\begin{array}{l}0.284^{*} \\
(0.170)\end{array}$ \\
\hline Discr. on job or job loss (d) & $\begin{array}{l}-0.017 \\
(0.091)\end{array}$ & & $\begin{array}{c}0.190 \\
(0.128)\end{array}$ & & $\begin{array}{c}0.016 \\
(0.129)\end{array}$ & \\
\hline Age & $\begin{array}{c}0.005^{* * * *} \\
(0.002)\end{array}$ & $\begin{array}{c}0.005^{* * *} \\
(0.002)\end{array}$ & $\begin{array}{c}-0.003^{*} \\
(0.002)\end{array}$ & $\begin{array}{c}-0.003^{*} \\
(0.002)\end{array}$ & $\begin{array}{c}-0.008^{* * *} \\
(0.002)\end{array}$ & $\begin{array}{c}-0.008^{* * *} \\
(0.002)\end{array}$ \\
\hline Female (d) & $\begin{array}{l}-0.039 \\
(0.028)\end{array}$ & $\begin{array}{l}-0.038 \\
(0.028)\end{array}$ & $\begin{array}{l}-0.007 \\
(0.030)\end{array}$ & $\begin{array}{l}-0.005 \\
(0.030)\end{array}$ & $\begin{array}{c}-0.212^{\text {*** }} \\
(0.037)\end{array}$ & $\begin{array}{c}-0.212^{* * *} \\
(0.037)\end{array}$ \\
\hline Education 10-13 (d) & $\begin{array}{c}0.079^{* * *} \\
(0.029)\end{array}$ & $\begin{array}{c}0.078^{* * *} \\
(0.029)\end{array}$ & $\begin{array}{l}-0.014 \\
(0.031)\end{array}$ & $\begin{array}{l}-0.013 \\
(0.031)\end{array}$ & $\begin{array}{c}-0.151^{* * *} \\
(0.041)\end{array}$ & $\begin{array}{c}-0.153^{* * *} \\
(0.041)\end{array}$ \\
\hline Education $14+(d)$ & $\begin{array}{c}0.130^{* * * *} \\
(0.032)\end{array}$ & $\begin{array}{c}0.130^{* * * *} \\
(0.032)\end{array}$ & $\begin{array}{l}-0.018 \\
(0.059)\end{array}$ & $\begin{array}{l}-0.014 \\
(0.060)\end{array}$ & $\begin{array}{c}-0.190^{* *} \\
(0.074)\end{array}$ & $\begin{array}{c}-0.189^{* *} \\
(0.074)\end{array}$ \\
\hline Pseudo $R^{2}$ & 0.027 & 0.027 & 0.008 & 0.010 & 0.047 & 0.049 \\
\hline Observations & 869 & 869 & 869 & 869 & 869 & 869 \\
\hline
\end{tabular}

Source: Authors' calculations using SHARELIFE data.

Notes: Marginal effects; robust standard errors in parentheses. ${ }^{*} p<0.1,{ }^{* *} p<0.05,{ }^{* * *} p<0.01$. (d) for discrete change of dummy variable from 0 to 1. 
Figure 1: Duration of individual jobs in which respondents experienced discrimination or job loss.

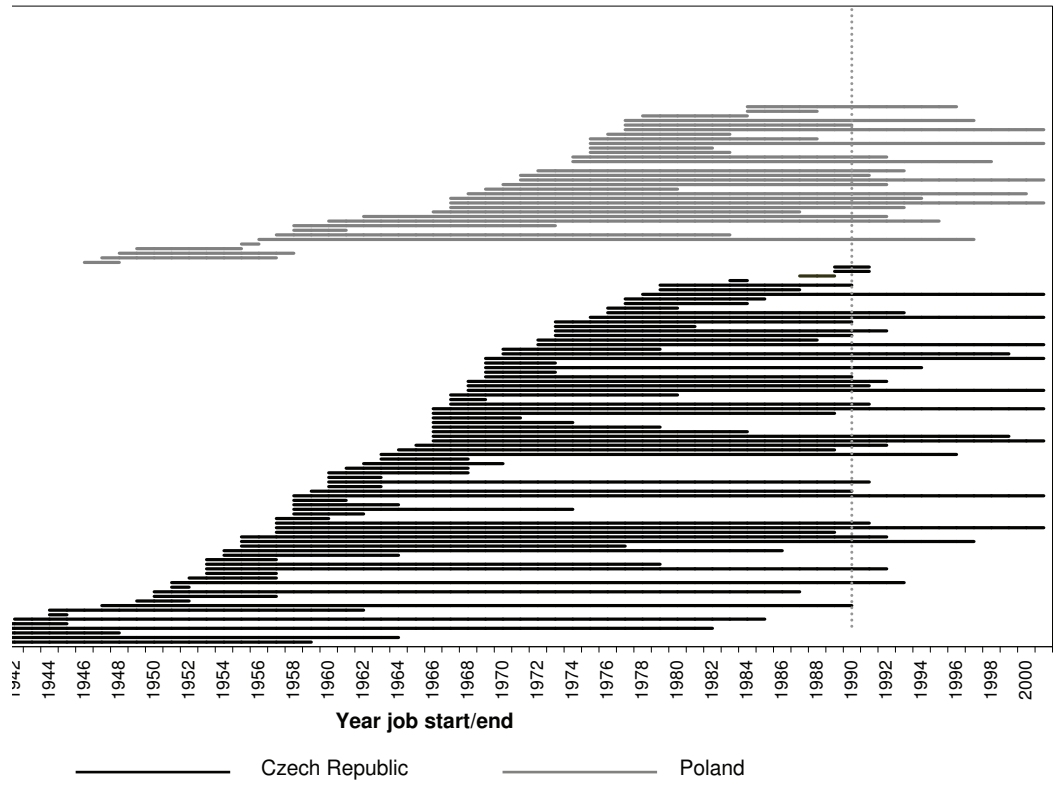

Source: Authors' calculations using SHARELIFE data. 